\title{
RECIDIVISM AS A MEASURE OF THE EFFECTIVENESS OF SANCTIONS: EXPERIENCE FROM THE CZECH REPUBLIC
}

\author{
JAN TOMÁŠEK \\ Institute of Criminology and Social Prevention \\ E-mail: jtomasek@iksp.justice.cz \\ JAN ROZUM \\ Institute of Criminology and Social Prevention \\ E-mail: jrozum@iksp.justice.cz
}

\begin{abstract}
Recidivism is one of the measures that can be used to evaluate the effectiveness of sanctions imposed by the criminal justice system. The article summarizes findings from the most extensive research of this type in the Czech Republic. The sample included a total of 4,233 individuals sentenced to house arrest, community service, suspended sentences with supervision or released from prison in 2012. Recidivism was defined as a new record in the Criminal Register in 2014. It was revealed that $48.1 \%$ of the sample re-offended in the two year period. While the type of sanction imposed on the offender had a negligible impact, the likelihood of a new conviction was strongly linked to gender, age and previous criminal career. The significance of previous convictions and their number was confirmed also by the multivariate analysis using logistic regression. The importance of these findings is high and the recidivism should be monitored systematically in the Czech Republic. However, as the research showed, it is impossible to connect the effectiveness of crime control with simply finding "effective sanctions". Inevitably, the criminal policy must be understood as an integral part of social policy.
\end{abstract}

Key words: Recidivism; effectiveness of penal policy; alternatives to prison; criminal carreer

\section{Introduction}

The effectiveness of sanctions or other measures imposed by the criminal justice system can be evaluated by different criteria. Looking back in history suggests the approach to this problem changed often according to prevailing attitudes toward crime, its causes and the overall chances of offender's rehabilitation. In recent decades, however, there has been a clear trend in measuring the effectiveness of sanctions almost exclusively by recidivism (King, 2014). Some authors even write of a certain obsession with this criterion, which strikingly reflects the culture of "fear" or "risk" in which we live (McNeill, 2000). It must also be kept in mind that the use of recidivism as a measure of effectiveness has a number of methodological and other problems, and therefore should not be used without an appropriate critical approach. However, this is rarely encountered in public discourse on effective punishment. 
It should be noted that the very term recidivism is often ambiguously defined. As described by Marešová (Marešová et al., 2011), it can be understood to have at least three basic meanings, these being in the context of criminal law, criminal statistics and criminology. If we are interested in assessing the effectiveness of a particular type of sanction, the question is essentially limited to the relatively simple task of determining whether or not an individual sentenced for a previous criminal act committed another crime (Bushway, Brame, \& Paternoster, 2004). Methodologically, however, this is a rather complex task. Some studies are based on records of criminal prosecution, others on information about new convictions or even imprisonment (Israel \& Wing Hon Chui, 2006), but all are significantly limited by the fact they do not encompass the area of hidden crime.

It is widely known that not all offences are reported or detected by the police, and subsequently investigated, resolved, prosecuted and convicted. We can learn nothing of hidden crime from official databases kept by different components of the criminal justice system, which suggests the number of offenders is in fact always higher (Merrington \& Stanley, 2007). There are disputes on the extent of hidden crime. However, its degree is certainly largely affected by the intensity of formal and informal control, tolerance of victims and level of citizens' legal awareness (Gřivna, Scheinost, \& Zoubková, 2014). There are undoubtedly major differences in terms of the type of crime. As victimological research has shown, the percentage of victims that do not report the offence to the police differs significantly based on the seriousness of the crime or the damage, while various psychological aspects can also play a role, such as embarrassment, shame or fear of the offender (Tomášek, 2010). In addition, we must also take into account the different detection rates. The likelihood of the capture and subsequent conviction of the offender is much higher for some crimes than for others. Crime register will therefore always be a more reliable source of data on serious violent crime than petty property crime.

One of the ways to encompass hidden crime is through self-report studies, the essence of which is to anonymously question potential offenders about their criminal activity, regardless of whether it was officially registered or not. The well-known Cambridge Study in Delinquent Development, which applied this method, notes that although $93 \%$ of surveyed men admitted to committing at least one crime during their life so far, official criminal records could only be found for $29 \%$ of them. Thus there were 39 criminal offences detected in self-reports for every one official conviction, with almost half of all offences captured in self-reports committed by individuals who had never been convicted (Farrington, Coid, \& Harnett, 2006). It is precisely this type of conclusion that has led some experts to declare that recidivism (or reoffending) is a variable that cannot be objectively measured (King, 2014).

Work with official data on new convictions is complicated by further methodological problems. For example, Lloyd et al. (Lloyd, Mair, \& Hough, 1994) discuss the problem of the period for which recidivism should be monitored, as we cannot say with certainty there is no risk of criminal behaviour in the case of offenders who have not committed a crime for several years. The problem with different periods of tracking recidivism, which are usually determined by the authors of relevant criminological research, considerably limits their subsequent comparison. Although the first years after serving a sentence pose the greatest risk in terms of further criminal activity, the longer the period 
over which recidivism is monitored, the higher the percentage of offenders we can expect to find with new convictions. Lloyd also pointed out that the new convictions cannot be automatically identified as a new crime. There is always a certain time lag between the criminal act itself and the imposition of sanctions for its commission, which may give rise to a situation where the offender is sentenced for a crime in the monitored period, which had in fact already occurred before serving the sentence whose effect is being evaluated.

Another point worth considering is the appropriateness of the criterion of recidivism to assess the effectiveness of sanctions or other measures imposed by the justice system. As noted by King (King, 2014), most analyses perceive recidivism as a purely dichotomous event, i.e., in the sense of "all or nothing". If an individual has a record of a new conviction, this is taken as evidence that the relevant intervention failed. However, this devised measure for assessing the impact of various sanctions and measures on the lives of individuals is much too "harsh". For example, we can imagine a situation where the execution of certain sanctions helps solve some of the problems faced by the offender (for example, he/she finds a job and solves his/her debts thanks to the activities of the probation officer), but recidivism still occurs - yet identifying such an intervention as "ineffective" would be debatable at the very least. Similarly, the dichotomous concept of recidivism does not discern important changes in the offender's criminal career (for example, a transition from serious violent crime to petty property crime), or take into account the positive impact of sanctions in cases where individuals are deterred from criminal activity, at least for some time. More in-depth analyses should therefore also monitor the types of crime and interval after which a new conviction occurs.

Despite these objections, however, data on recidivism is indispensible for the rational development of criminal policy. Among other things, it provides feedback for different components of the criminal justice system that impose sanctions and other measures and ensure their execution (public prosecutors, the courts, the prison service and the probation service). In many countries, we can see efforts in recent years to ensure that data on recidivism becomes an integral part of standard criminal justice statistics. This is aided by the Council of Europe, which supports efforts to improve the collection of this data in all Member States, including for the purpose of mutual comparison. This data can also be applied to the development and improvement of instruments for identifying the risks of future reoffending.

\section{Monitoring recidivism in the Czech Republic}

Criminal recidivism is not systematically monitored in the Czech Republic in relation to imposed sanctions and their effectiveness. Although police and judicial statistics indicate what percentage of the total number of prosecuted or convicted individuals are repeat offenders, the specific sanctions or other measures imposed on these individuals in the past cannot be determined. The specific type of recidivism on which we have basic statistical data in our conditions is only recidivism in a penological or penitentiary sense (repeat prison sentences). In recent years, this data has become part of official statistics published by the Prison Service of the Czech Republic. Graph 1 is based on this data, tracking the offenders serving prison sentences in 2010-2015 and showing the rate of 
inmates not being in prison for the first time in the given year. If we consider the effectiveness of imprisonment on the basis of this data, it can certainly not be considered an effective intervention in terms of further criminal activity. In fact, roughly two thirds of convicted offenders committed further crimes, even though they had experienced prison, and often even repeated criminal offences.

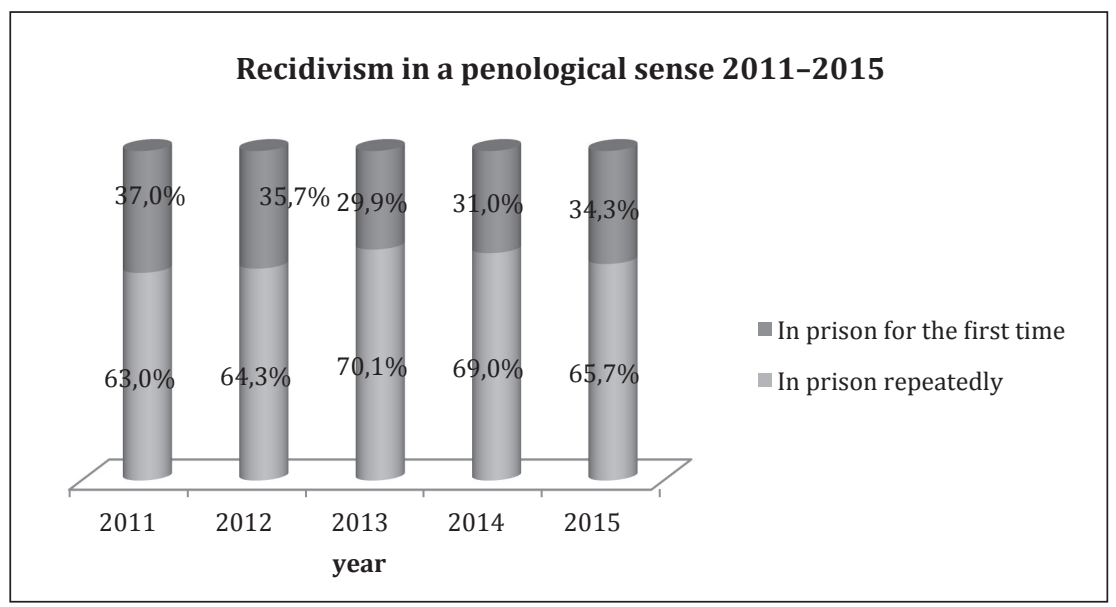

\section{Graph 1}

Source: The Prison Service statistics

To evaluate the effectiveness of other sanctions, we must rely solely on individual criminological studies. The database from which their authors can draw information on recidivism is primarily the Criminal Register. It is remarkable that in contrast to other countries, this source was long unused for criminological research in our conditions. This was critically pointed out by Novotný and Zapletal (Novotný \& Zapletal, 2001), who rightly assumed an analysis of this data would contribute to both clarifying the amount of crime, gaining a deeper understanding of criminal recidivism and assessing the effectiveness of imposed sanctions. The Criminal Register began to be used in this spirit by the Institute of Criminology and Social Prevention in its research after the year 2000. The first study was devoted to the effectiveness of supervision in case of offenders conditionally released from prison (parole). It encompassed a sample of 642 individuals released in 2003. New convictions during the period of supervision were registered in $39.9 \%$ of cases (Rozum, Kotulan, \& Tomášek, 2008).

Another criminal justice measure, whose effectiveness was studied through records of new convictions, was mediation between the offender and the victim of crime (Rozum et al., 2010). Data on 311 accused individuals who had undergone mediation in 2005 was analysed. Information on recidivism was collected in May 2009. It was found that about one quarter of the sample (25.4\%) had records of a new conviction. A less favourable figure emerged from a study of probation programmes for juveniles, which included data on 326 individuals who had completed such a programme in 2006. Recidivism was examined using the Criminal Register in September 2010, nearly four years after participation in the programme. The recidivism rate was $52 \%$, despite the fact the vast majority of 
offenders $(89.6 \%)$ had entered the programme as first-time offenders (Rozum, Kotulan, Špejra, \& Tomášek, 2011).

The most extensive research of its kind in the Czech Republic to date was compiled by the authors of this article as part of a research project on the effectiveness of penal policy, which was conducted in cooperation between the Institute of Criminology and Social Prevention and the Department of Social Work of the Faculty of Arts, Charles University (Scheinost, Rozum, Háková, Tomášek, \& Vlach, 2015). For the first time there was a direct comparison of the effectiveness of different types of sanctions in our country. The research sample included a total of 4,233 individuals. Their selection was based on two criteria, the exact period in which the imposed sanction or measure was recorded in the Criminal Register (1 April to 30 June 2012), and the type of sanction. Given the project topic, the authors were interested in persons sentenced to house arrest (126 offenders in our sample), community service $(2,232)$ and suspended sentences with supervision $(1,067)$. The fundamental question in terms of effectiveness was how the recidivism rate would vary from the recidivism rate of persons sentenced to unconditional imprisonment. For this reason a control group was created, which included persons previously sentenced to imprisonment, whose sentences has ended during the three months in 2012 (808 offenders). The sentence had either ended by serving their entire term (499), conditional release from prison with supervision (75), or without supervision (234). Recidivism was then defined as another record in the Criminal Register, which was traced in July 2014. Therefore this covered a roughly two-year period during which further criminal activity was monitored.

Most of the sample was male (90.6\%) and of Czech nationality (92.5\%). The average age in the year 2012 was 33 . The youngest individual had only just reached the age of criminal liability (15 years of age), the oldest being 78 . Almost half of the sample was under thirty years of age, $74.2 \%$ of the sample was under 40 . Table 1 shows the sample divided into individual age categories combined with gender.

Table 1: Sample by the age and sex

\begin{tabular}{|l|c|c|}
\hline Age & Men & Women \\
\hline $15-18$ & 3.1 & 1.0 \\
\hline $19-21$ & 11.9 & 11.5 \\
\hline $22-29$ & 28.5 & 27.3 \\
\hline $30-39$ & 30.7 & 34.0 \\
\hline $40-49$ & 17.7 & 19.3 \\
\hline $50-59$ & 6.4 & 6.0 \\
\hline 60 and more & 1.7 & 1.0 \\
\hline Total & $100.0 \%$ & $100.0 \%$ \\
\hline
\end{tabular}

In terms of criminal activity, the biggest representation was undeniably theft. It was committed by 1.382 offenders, i.e. almost one-third of the sample (32.6\%). Other offences frequently represented in the sample were obstruction the execution of an official decision (14.5\%) and neglect of duty of sustenance (14.1\%). More serious crimes against life and health were on the contrary quite rare (only $3.9 \%$ of the sample were convicted for 
assault and $0.9 \%$ for burglary). At the same time, however, only about $12 \%$ of the sample had been convicted for the first time in 2012. Others entered the study as "recidivists" for whom almost five previous convictions could be found in the Criminal Register on average (4.9; st. deviation 4.2). Table 2 provides a more detailed overview. It is worth noting that the most extreme case was a man with 39 previous convictions, followed by 34 and 30 convictions by those next in line. A total of 46 people (1.0\%) had more than twenty convictions; more than one tenth of the entire sample was individuals with a minimum of ten convictions. A third of repeat offenders (33.4\%) had also experienced imprisonment in the past (men differed significantly here at $39.3 \%$ from women at $24.5 \%$ ).

Table 2: The number of previous convictions

\begin{tabular}{|l|c|}
\hline Convictions & \\
\hline 0 & 12.0 \\
\hline 1 & 16.3 \\
\hline 2 & 15.9 \\
\hline 3 & 11.3 \\
\hline 4 & 8.7 \\
\hline $5-9$ & 25.3 \\
\hline 10 and more & 10.5 \\
\hline Total & $100.0 \%$ \\
\hline
\end{tabular}

An important factor in the criminological point of view is the age at which individuals first come into contact with the criminal justice system. Research has convincingly shown that the sooner the first conviction occurs, the higher the probability an individual's criminal career will last longer and the number of committed offences higher (Farrington, 2008). In fact, this is such an important predictor of reoffending that most instruments for identifying the risks of recidivism work with it. A check of the Criminal Register found that the average age of first conviction in our sample was 23.5 years (st. deviation 8.1). More than half of the sample (58\%) committed their first crime before 22 years of age, $82.4 \%$ of the sample before the age of 30 . Table 3 gives a more detailed overview of the age of offenders on their first record in Criminal Register, which also illustrates the statistically significant differences between men and women (criminal careers were typically commenced by men in our sample at a younger age than women). The average age of first conviction for men was 23.1, while this was 26.8 for women.

In accordance with the findings of developmental criminology, it was confirmed that the sooner an individual commits their first crime, the greater the total number of offences they can be expected to commit. The Pearson correlation coefficient for this relationship in our sample was -0.33 (significant $\mathrm{p}<0.01$ ), which is aptly illustrated by Graph 2 .

As previously stated, the effectiveness of sanctions was examined in July 2014. In other words, we investigated whether there had been any further convictions during the two year period. The resulting figure is far from positive $-2,038$ individuals had a new record in the Criminal Register, i.e. $48.1 \%$ of our sample! Basically, every second person re- 
Table 3: Age of the first conviction by sex

\begin{tabular}{|l|c|c|}
\hline Age & Men & Women \\
\hline $15-18$ & 30.2 & 10.3 \\
\hline $19-21$ & 29.9 & 28.0 \\
\hline $22-29$ & 23.7 & 30.8 \\
\hline $30-39$ & 10.9 & 21.0 \\
\hline $40-49$ & 3.8 & 8.0 \\
\hline $50-59$ & 1.1 & 1.5 \\
\hline 60 and more & 0.5 & 0.5 \\
\hline Total & $100.0 \%$ & $100.0 \%$ \\
\hline
\end{tabular}

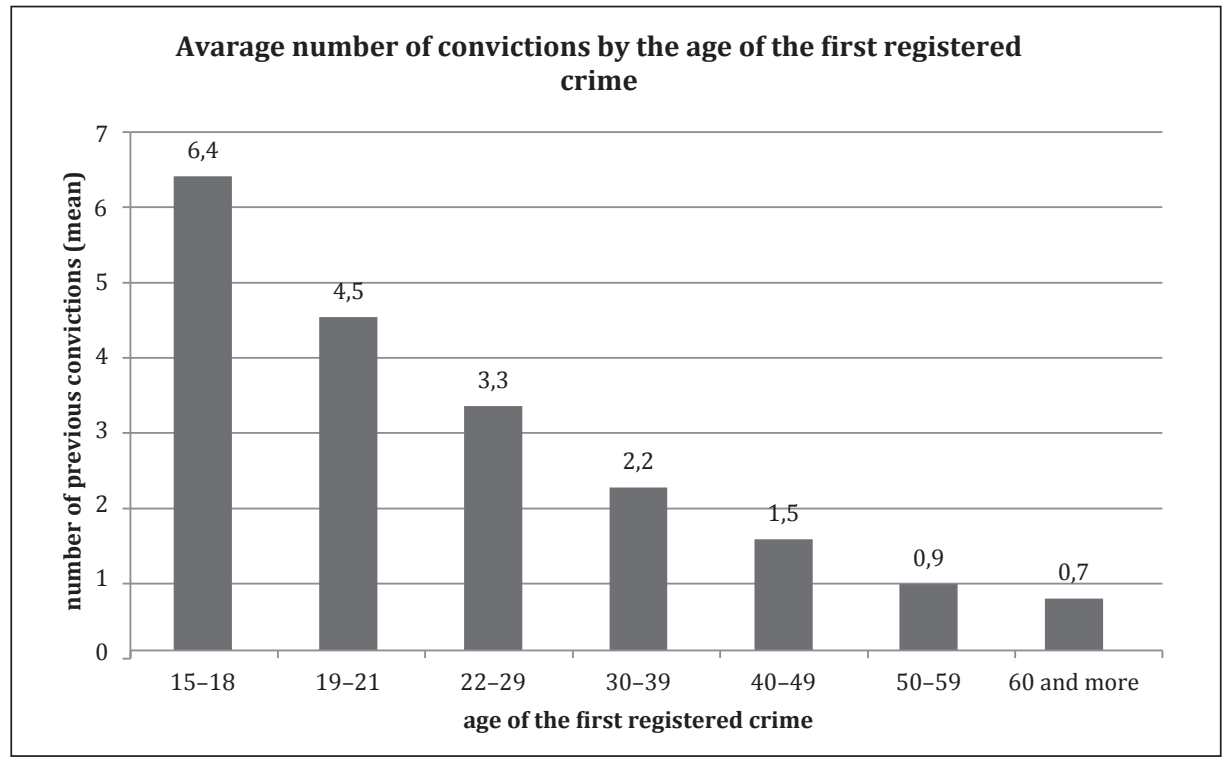

\section{Graph 2}

offended in the two year period. Moreover, cases where recidivism had occurred repeatedly were no exception. As Table 4 shows, a quarter (24.3\%) of our sample had more than one new record in the Criminal Register. The average number of new convictions for the entire sample was 0.96 (st. deviation 1.4), but almost two acts for the group of convicted re-offenders (1.99; st. deviation 1.4). One offender had an almost unbelievable fourteen new convictions, and three others eleven convictions. A total of 4.065 new records of convictions were attributed to our sample. We also monitored the time interval in which new convictions appeared in the Criminal Register. For two thirds of re-offenders $(65.9 \%)$ this was in the first year (for $37.1 \%$ in the first six months), the remainder $(34.1 \%)$ at an interval of one to two years. 
Table 4: Number of new convictions in Criminal Register

\begin{tabular}{|l|c|c|}
\hline \multicolumn{1}{|c|}{ Convictions } & Offenders & \% \\
\hline 0 & 2193 & 51.8 \\
\hline 1 & 1013 & 23.9 \\
\hline 2 & 507 & 12.0 \\
\hline 3 & 279 & 6.6 \\
\hline 4 & 123 & 2.9 \\
\hline 5 and more & 118 & 2.8 \\
\hline Total & 4,233 & 100.0 \\
\hline
\end{tabular}

The premise that one of the sanctions would emerge as more effective than the others was not confirmed at all. Although it could be said the largest percentage of repeat offenders were those given suspended sentences with supervision (49.4\%) and the lowest were among those sentenced to prison (45.0\%), the observed differences were not statistically significant. As indicated in Table 5, the type of sanction imposed on the offender by the court had a negligible impact on whether or not they subsequently committed another crime. Significant factors that influence criminal behaviour probably lie beyond the reach of the criminal justice system, which is a finding that regularly appears in criminological studies (Soothill, Fitzpatrick, \& Francie, 2009). As documented in earlier studies by the Institute of Criminology and Social Prevention, most experts working in the Czech criminal justice system are well aware of this fact (Scheinost, Háková, Rozum, Tomášek, \& Vlach, 2014).

Table 5: Recidivism and the type of sanction

\begin{tabular}{|l|c|c|}
\hline Sanction & $\begin{array}{c}\text { Recidivism rate } \\
\text { (\%) }\end{array}$ & $\begin{array}{c}\text { Average number of new } \\
\text { convictions }\end{array}$ \\
\hline Community service & 48.8 & 0.95 \\
\hline Suspended sentence with supervision & 49.4 & 1.01 \\
\hline House arrest & 46.0 & 1.01 \\
\hline Prison & 45.0 & 0.92 \\
\hline Total & 48.1 & 0.96 \\
\hline
\end{tabular}

While the impact of the type of imposed sanction on recidivism proved controversial, a different finding applies to basic demographic data on convicted offenders. The likelihood of a new conviction was strongly linked to gender. The men in our sample re-offended significantly more often than women $(48.8 \%$ vs. $41.5 \%$; $p<0.01)$ and the average number of new records in the Criminal Register was also higher, although the difference was not statistically significant $(0.97$ vs. 0.92$)$. Age is considered as a very reliable predictor of recidivism in criminological literature (Farrington, 2008). As illustrated by Graph 3, our study also confirmed the importance of this factor. With the exception of the oldest category of offenders (over 60 years of age), the rate of recidivism noticeably declined with age. While $62.1 \%$ of juvenile offenders had records of a new conviction, 
this was less than $50 \%$ for those over the age of 30 (and only about one-third in the over 50 category). In the category of oldest offenders who defy this trend, it must be said that many crimes were related to driving (driving without a license or driving under the influence). Therefore this relates to criminal activity the police can detect more easily than other types of crime, and catching and subsequently convicting the offender is thus more likely. Moreover it may be said the police has systematically focused on this phenomenon in recent years thanks to new technical equipment (detectors) and checks on Czech roads are fairly common.

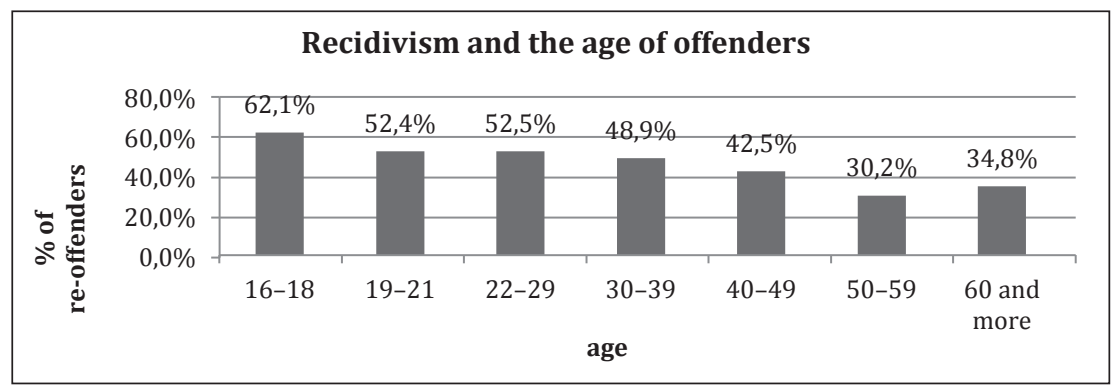

Graph 3

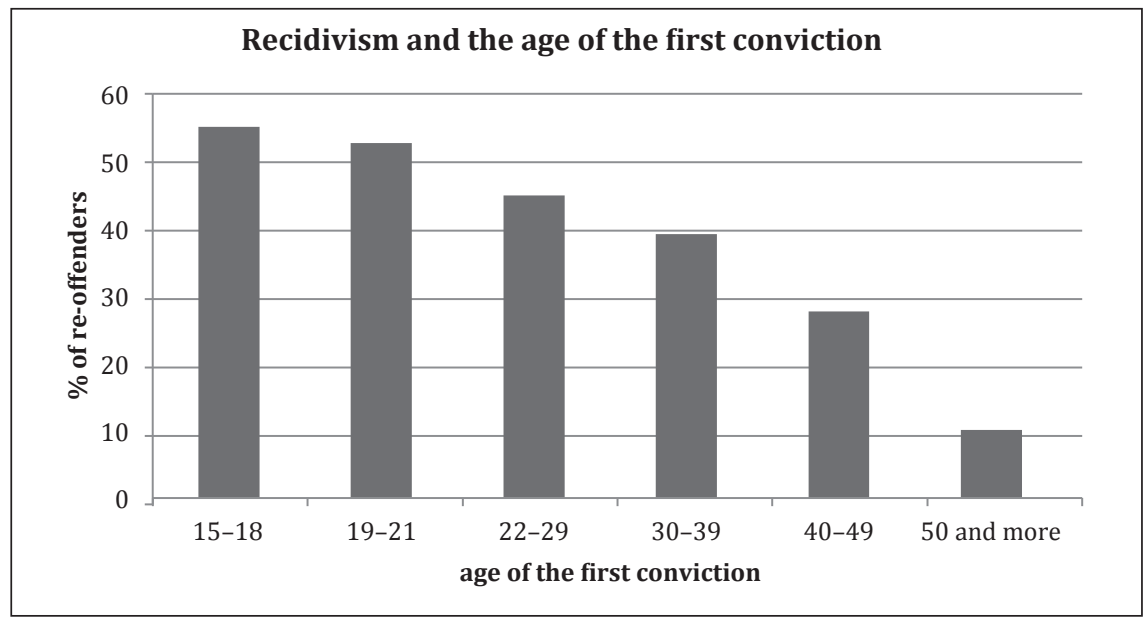

\section{Graph 4}

The analysis also confirmed the importance of the age at which the individual first came into contact with the criminal justice system (the sooner an individual was first sentenced, the greater the likelihood a new conviction would appear on their criminal record in the monitored two year period). This relationship is illustrated in Graph 4. However, the correlation itself is only weak $(r=-0.19, \mathrm{p}<0.01)$.

As expected, a crucial factor associated with a higher probability of recidivism was the offender's criminal past. People who had a previous criminal record reoffended in $51.4 \%$, while those who entered our sample as first-time offenders only reoffended in $24.1 \%$ 
$(\mathrm{p}<0.001)$. As expected, the average number of records of new convictions in the Criminal Register also differed. While this was 1.03 in the former group; for first-time offenders this was only $0.44(\mathrm{p}<0.001)$. Graph 5 demonstrates a clear relationship between the number of previous convictions and risk of recidivism - if we divide our sample into categories according to the number of previous convictions, it is evident this is closely related to the percentage of re-offenders with previous records (differences between individual categories were statistically significant at $\mathrm{p}<0.001)$.

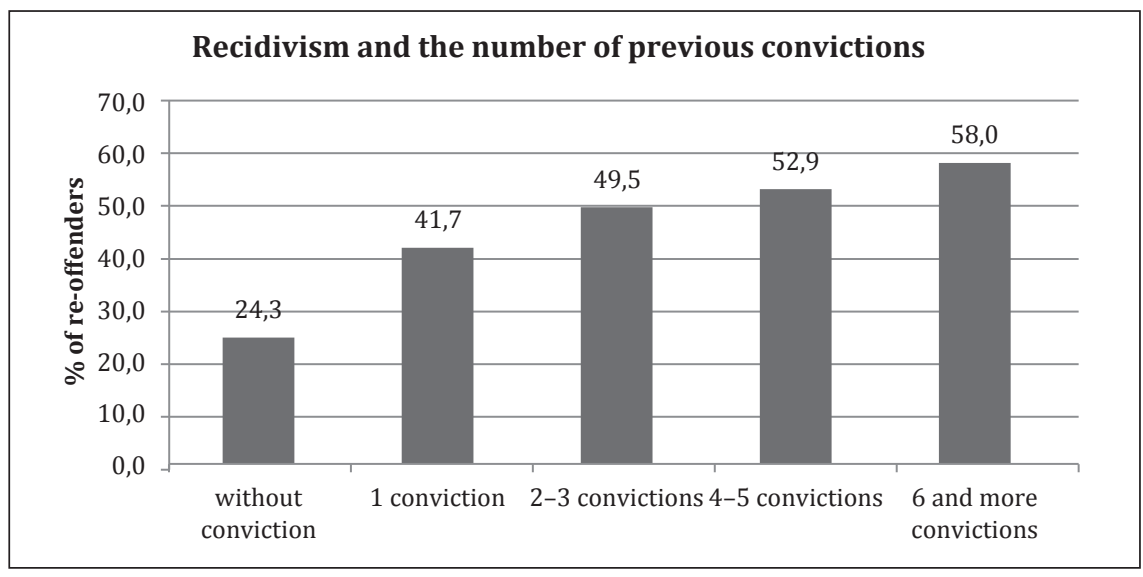

\section{Graph 5}

If we only focus on convicted offenders with a previous record in the Criminal Register, it can be said that a higher rate of recidivism could be traced to people who had been sentenced to prison in the past $(56.3 \%)$ - while for individuals who had not been sentenced to such punishment in the past, this was $48.4 \%(\mathrm{p}<0.001)$. There was also a statistically significant difference between these two groups in the average number of further convictions recorded in the Criminal Register in 2012 (1.19 vs. 0.94; p < 0.001). With regard to the type of criminal activity, the number of re-offenders was higher among perpetrators of crimes against property (theft), and lowest among perpetrators of crimes against life and health.

\section{Multivariate analysis of recidivism}

The nature of the data collected in our study also offered the opportunity for multivariate analysis using logistic regression. Unlike bivariate analyses, the conclusions of which are summarised above, this method allows us to evaluate how each factor entered in the analysis contributes to explanation of our dependent variable while controlling for all other factors. The model is shown in Table 6. We estimate chances (odds ratio, OR) that a new criminal record appears in the Criminal Register, for an offender convicted in 2012 and included in our sample, over the next two year period. The dependent variable is thus recidivism, or a new entry in the Criminal Register after 2012 ( $1=$ yes). As 
independent variables, gender, the convicted offender's current age, the age at which he or she committed their first offence registered in the Criminal Register, the type of crime for which he or she was convicted in 2012 (the analysis considers only the most frequent types of crime, i.e. theft, neglect of duty of sustenance, obstruction the execution of an official decision and assault), the sanction imposed for this crime, previous convictions (whether he or she has been previously sentenced), and finally the number of previous convictions were entered in the analysis. These factors can be considered as relevant in terms of criminology and its findings on criminal careers or recidivism. The model was computed for 2,761 individuals.

Table 6: The influence of different factors on recidivism (logistic regression)

\begin{tabular}{|l|c|c|c|}
\hline Variables & b & & OR \\
\hline Sex $(1=$ man) & 0.116 & & 1.123 \\
\hline Age & -0.061 & $* * *$ & 0.941 \\
\hline Age of the first conviction & 0.016 & $*$ & 1.016 \\
\hline Typ of crime 2012 (ref = theft) & & & \\
\hline neglect of compulsory maintenance & -0.059 & & 0.942 \\
\hline obstruction the execution of an official decision & -0.139 & & 0.870 \\
\hline assault & -0.837 & $* * *$ & 0.433 \\
\hline Sentence in 2012 (ref = prison) & & & \\
\hline house arrest & -0.049 & & 0.952 \\
\hline community service & 0.394 & $* * *$ & 1.483 \\
\hline suspended sentence with supervision & 0.555 & $* * *$ & 1.742 \\
\hline Previous conviction (1 = yes) & 0.858 & $* * *$ & 2.359 \\
\hline Number of previous convictions & 0.137 & $* * *$ & 1.147 \\
\hline Constant & 0.098 & & \\
\hline Pseudo R & & & 0.129 \\
\hline Cox \& Snell R & & & 0.096 \\
\hline
\end{tabular}

$\mathrm{N}=2,761$

${ }^{* * *} \mathrm{p}<0.001 ;{ }^{*} \mathrm{p}<0.05$

Contrary to bivariate analysis, there were no differences between men and women. Age, however, remains a significant predictor of recidivism in our sample suggesting that older people have lower chance to reoffend than their counterparts. With regard to the type of criminal activity we find out that compared to those who were convicted of theft in 2012, perpetrators of assault $(\mathrm{OR}=0.433)$ reoffended less. This confirms the fact that recidivism is somewhat more common among perpetrators of crime against property. Previous convictions and their number, i.e. whether an individual had been convicted before 2012 $(\mathrm{OR}=2.359)$ and the number of convictions they had in the Criminal Register $(\mathrm{OR}=$ 1.147) also proved to be statistically significant. The chance of recidivism is thus increased by the fact an individual was convicted before 2012, and the number of such convictions. 
As regards the type of sanction, the results of this analysis are very interesting. While bivariate analyses led us to conclude this factor was almost negligible in terms of subsequent recidivism, the regression model speaks in favour of imprisonment. By comparison, offenders sentenced to other types of punishment re-offended significantly more often (except of house arrest). This was especially true for conditional sentences with supervision $(\mathrm{OR}=1.742)$ and community service $(\mathrm{OR}=1.483)$. Such a conclusion supports the theory that imprisonment has the strongest potential of all monitored sanctions in terms of individual prevention (experience with imprisonment is so unpleasant for convicted offenders that it deters them from further crime). However, in our opinion such an interpretation of the resulting model would not be correct. We are afraid this is more the effect of certain methodological problems this analysis faced.

What matters above all is the nature of the Criminal Register, or the data it offers. As we mentioned, a record of a new conviction cannot be seen as clear evidence of recidivism. The problem lies in the fact that the record itself is not consistent with the actual time the act was committed - on the contrary, there is always a certain time lag between the commission of a crime and the offender's conviction, the length of which depends on the work of individual criminal justice authorities. For our study, this means that some of the offences that appeared in the Criminal Register in the monitored period 2012-2014, were in fact committed earlier (i.e. before the date we used for the inclusion of selected individuals in our sample). This fact may not play a crucial role in the overall results, however if it significantly manifests anywhere, it is precisely in relation to the type of imposed sanction. For individuals included in the sample based on a prison sentence, there was naturally a much smaller chance of a new conviction appearing in the Criminal Register after 2012, committed in a short period before that compared to other sanctions (prevented by their incarceration). Extra attention must therefore be devoted to the category of records that appear in the Criminal Register in the first six months of the monitored period - where the risk of a time shift is greatest.

Table 7 supports such reasoning. It captures individuals for whom we found new records in the Criminal Register after 2012 (a total of 2,040 convicted offenders), with the time interval at which this new record appeared after the record in 2012 for each sanction. It is no coincidence that the shortest of these (less than 6 months) is represented considerably less often in cases of imprisonment than for other sanctions (just 25.6\%). Of course, we have no certainty whether these facts are responsible for the difference between the results of bivariate analyses and our regression model. For such a conclusion we would need data of a different nature than records of new convictions (ideally directly

Table 7: Type of sanction and the time of new conviction in Criminal Register

\begin{tabular}{|l|c|c|c|c|}
\hline New conviction & $\begin{array}{c}\text { Community } \\
\text { service }\end{array}$ & $\begin{array}{c}\text { Suspended } \\
\text { sentence with } \\
\text { supervision }\end{array}$ & House arrest & Prison \\
\hline Less than 6 months & 41.6 & 35.3 & 41.4 & 25.6 \\
\hline 6 months - 1 year & 27.5 & 29.7 & 31.0 & 31.3 \\
\hline More than 1 year & 30.9 & 35.0 & 27.6 & 43.1 \\
\hline In total & $100.0 \%$ & $100.0 \%$ & $100.0 \%$ & $100.0 \%$ \\
\hline
\end{tabular}


related to the solved crime). This could be obtained, for example, through a study of court records, but such an analysis would be impossible for such a large sample as that chosen for our study.

In addition to the aforementioned distortion, there is also an objection that some categories of convicted offenders were not included in the regression model for methodological reasons, and that as a result, the sample used for logistic regression could have different characteristics to the whole research sample. Likewise, we must remind that an assessment of the rehabilitative effect of some alternatives to prison (mainly community service and probation) is controversial, as the time limit we had for monitoring was too short and the punishment itself may not have been fully served.

\section{Conclusion}

This study of the Institute of Criminology and Social Prevention received a strong response from the professional public. This can be seen as proof that monitoring the effectiveness of sanctions according to the criterion of recidivism can significantly influence the ongoing debate on criminal policy and its overall direction. There is no doubt that concrete data on the rate of recidivism by convicted offenders sentenced to different types of sanctions is the most promising avenue for debate on effective criminal policy to shake its speculative, and sometimes ideological or populist tendencies. Knowing the facts enables the issue to be approached rationally, and in a situation where the effect of alternative sanctions seems to be very similar to the effect of imprisonment, it opens up the chance to give greater consideration to such criteria as economic cost. If we compare prison index in the Czech Republic to that of more economically developed countries in the European Union, it is clear that any opportunity must be taken to change, or at least significantly influence the conservative views of politicians and the public on the options for punishing offenders.

Criminological studies dealing with sanctions and their effect will continue to emerge from the Criminal Register. The question is whether, given the seriousness and importance of this issue to society as a whole, they can satisfy the need for basic information and knowledge. We believe that crime and the effectiveness of various measures for its reduction are such a fundamental issue that we should strive for the necessary data to be systematically monitored over the long term, i.e. without depending on the current objectives and capabilities of individual research institutes. Such a solution is supported by the fact that all data is now processed electronically, and the implementation of this type of analysis is therefore a question of a merely technical nature. We believe that information on the effectiveness of selected sanctions could become a standard part of criminal justice statistics in the future.

At the same time, however, the study showed that connecting the effectiveness of criminal policy with simply finding "effective sanctions" is impossible. The impact of criminal justice on the criminal careers of convicted offenders is limited and the decisive factors in terms of recidivism or desistance are outside its reach, particularly in areas such as employment, housing or family. Criminal policy must therefore be understood as an integral part of social policy, as the true effectiveness of sanctions can only be considered 
if they encourage and promote natural positive changes in the lives of offenders, both at an individual and social level.

\section{REFERENCES}

Bushway, S., Brame, R., \& Paternoster, R. (2004). Connecting desistance and recidivism: measuring changes in criminality over the lifespan. In Maruna, S., \& Immarigeon, R. After Crime and Punishment: Pathways to Offender Reintegration. (pp. 85-101). Cullompton: Willan Publishing.

Farrington, D. (2008). Integrated developmental and life-course theories on offending. London: Transaction Publishers.

Farrington, D., Coid, J., \& Harnett, L. (2006). Criminal careers up to age 50 and life success up to age 48: new findings from the Cambridge Study in Delinquent Development. London: Home Office.

Gřivna, T., Scheinost, M., \& Zoubková, I. (2014). Kriminologie. Praha: Wolters Kluwer.

Israel, M., \& Chui, W. H. (2006). If 'something works' is the answer, what is the question? Supporting pluralist evaluation in community corrections in the United Kingdom. European Journal of Criminology, 3(2), 181-200.

King, S. (2014). Desistance transitions and the impact of probation. London: Routledge.

Kubrin, C., Stucky, T., \& Krohn, M. (2009). Researching Theories of Crime and Deviance. Oxford: Oxford University Press.

Langan, P., \& Levin, D. (2002). Recidivism of Prisoners Released in 1994. Federal Sentencing Reporter, 15(1), 58-65.

Lloyd, C., Mair, G., \& Hough, M. (1994). Explaining reconviction rate: A critical analysis. London: Home Office.

Marešová, A., Blatníková, Š., Kotulan, P., Martinková, M., Štěchová, M., \& Tamchyna, M. (2011). Kriminální recidiva a recidivisté: charakteristika, projevy, možnosti trestní justice. Praha: IKSP.

McNeill, F. (2000). Defining effective probation: frontline perspectives. The Howard Journal of Criminal Justice, 39(4), 382-397.

Merrington, S., \& Stanley, S. (2007). Effectiveness: who counts what?. In Gelsthorpe, L., \& Morgan, R. Handbook of Probation. (pp. 428-458). Cullompton: Willan Publishing.

Newburn, T. (2007). Criminology. Cullompton: Willan Publishing.

Novotný, O., \& Zapletal, J. (2001). Kriminologie. Praha: Eurolex Bohemia.

Roberts, J., \& Hough, M. (2005). Understanding public attitudes to criminal justice. Maidenhead: Open University Press.

Rozum, J., Kotulan, P., Luptáková, M., Scheinost, M., Tomášek, J., \& Špejra, M. (2010). Uplatnění mediace v systému trestní justice II. Praha: IKSP.

Rozum, J., Kotulan, P., Špejra, M., \& Tomášek, J. (2011). Probační programy pro mladistvé. Praha: IKSP.

Rozum, J., Kotulan, P., \& Tomášek, J. (2008). Účinnost dohledu u osob podminéně propuštěných. Praha: IKSP.

SCCJR. (2012). Reducing Reoffending: Review of Selected Countries. Glasgow: The Scottish Centre for Crime and Justice Research.

Scheinost, M., Háková, L., Rozum, J., Tomášek, J., \& Vlach, J. (2014). Sankční politika pohledem praxe. Praha: Institut pro kriminologii a sociální prevenci.

Scheinost, M., Rozum, J., Háková, L., Tomášek, J., \& Vlach, J. (2015). Trestní sankce - uplatňování, mediální prezentace a recidiva. Praha: IKSP.

Soothill, K., Fitzpatrick, C., \& Francie, B. (2009). Understanding Criminal Careers. Cullompton: Willan Publishing.

Tomášek, J. (2010). Úvod do kriminologie - jak studovat zločin. Praha: Grada. 